FACTA UNIVERSITATIS

Series: Philosophy, Sociology, Psychology and History Vol. 17, N 3, 2018, pp. 199 - 212

https://doi.org/10.22190/FUPSPH1803199D

Review Paper

\title{
STUDENTS' JOB QUALITY PREFERENCES IN A COMPARATIVE PERSPECTIVE
}

UDC 316.644-057.87:331.101.3(497.11+497.17+497.2)

\section{Gorana Đorić, Gordana Stojić}

University of Niš, Faculty of Philosophy, Department of Sociology, Serbia

\begin{abstract}
This paper focuses on the students' perception of job quality in Serbia, Macedonia and Bulgaria. The starting assumption is that the students' job preferences are shaped by the socioeconomic conditions in these societies. On the other hand, we assume that the importance they attach to different job characteristics depends on their country of origin, sex, employment status and education level of their parents, and class affiliation.
\end{abstract}

Key words: Job quality, Students, Serbia, Macedonia, Bulgaria.

\section{INTRODUCTION}

When it comes to work, two questions attract attention in contemporary society: job openings and job quality. Young generations entering the labor market face both issues and often have to choose between no job and a job with unfavorable quality. In the last decades, the world has faced changes in the value system, on the one hand, and in the sphere of work, on the other (Hauff and Kirchner 2014). These changes are even more pronounced in post-socialist countries in transition (Vecerník 2003). Economic, social, political, and cultural changes affect both the objective characteristics of jobs (wages, job security, employment security, legal protection) as well as the subjective ones (what is a good job for a person). This leads to the following question: what are the expectations that young people attach to their future work?

\section{THEORETICAL BACKGROUND AND PREVIOUS RESEARCH}

Two different traditions can be identified regarding the conceptualization of job quality. The objective tradition focuses on "the features of jobs that meet workers' needs from work", while the subjective tradition sees job quality as "the 'utility' that a worker

Received November 19, 2018 / Accepted December 19, 2018

Corresponding author: Gorana Đorić

University of Niš, Faculty of Philosophy, Ćirila i Metodija 2, 18000 Niš, Serbia

E-mail: gorana.djoric@filfak.ni.ac.rs 
derives from his or her job" (Eurofound 2012, 10). The subjective aspects of job quality are important for workers' well-being, and work value serves as principles for the evaluation of work outcomes and settings, as well as for the choice among different work alternatives (Ross et al. 1999, 54).

Different terms have been used to express the relationship that people have toward their work: work values, work ethics, job preferences, work orientation and so on. Work values refer to the meanings that individuals attach to perceived job characteristic (Kalleberg 1977, 127). They pertain to desirable end-states (high pay) or behavior (working with people) (Ross et al. 1999, 54). Most researchers distinguish between intrinsic (self-actualization or cognitive) and extrinsic (security or material or instrumental) work values. The adequacy of this dichotomy has been questioned (Elizur 1984) so a third category has been added social or relational values. Ross et al. $(1999,55)$ single out the fourth dimension of work values - prestige or power which refers to prestige, authority, influence and achievements in work. Kalleberg $(1977,128)$ differentiates between six dimensions of work: intrinsic, four extrinsic (convenience, financial dimension, relationship with co-workers and opportunities for a career) and resource adequacy.

How different job facets are valued by people depends on personal characteristics, but also on "time, place, culture and class" (Tilly \& Tilly, in Watson 2008, 233). Two groups of sociological theories deal with work values (Kalleberg and Marsden 2013, 256). Selection perspectives focus on the influence of factors outside of work on the shaping of work values, especially social origins and parental influences during early socialization. Work socialization perspectives stress the impact of work-related experience (workplace occupational socialization and availability of different rewards) on workers' preferences.

Social, economic, political and cultural context influence one's attitudes toward favorable job characteristics. It means that different preferences should be found in different countries, but also between people with different socio-economic traits and consequently, different chances on the labor market. What is a good job for worker depends on "how this job's characteristics stack up against perceived alternatives" (Galvan 2012, 162, 173). People tend to adapt their expectations to the opportunities available to them. High levels of the unemployment rate and widespread precarious forms of employment, for example, can contribute to a high evaluation of job security. On the other hand, in every society there are "certain basic notions of what is desirable" (Watson 2008, 233) so work orientations should be situated in the wider cultural context.

There are differences in the importance people place on various job characteristics depending on their gender, class affiliation, age, education. Members of new cohorts who enter the labor market (i.e. millennials) have different skills and experiences, and likely, different job preferences than previous cohorts of the labor force: for example, they tend to see their work in more instrumental terms and place great importance on income (Kalleberg and Marsden 2013, 258, 268). Working time is more important for women than for men and high skill workers value jobs that allow them to use their abilities and have an initiative (Carrée et al. 2012, 8). Middle class members tend to seek intrinsic, while the working class is likely to opt for extrinsic job traits (Watson 2008, 234-235). Class differences may reflect cultural differences or different opportunities to realize rewards from jobs (Kalleberg and Marsden 2013, 256).

This paper focuses on the perception of the job quality of students from Serbia, Macedonia and Bulgaria. Serbia, Macedonia and Bulgaria have crossed the path from socialist to capitalist society. All three countries belong to medium level developed countries (UNDP 
2013). Economic and labor market indicators show that Bulgaria has slightly better performances than the other two countries. Bulgaria is also a member of the EU, providing citizens with opportunities for employment in the European labor market. High rates of unemployment, widespread informal work, low legal protection and poor working conditions, as well as low pay influence the perception of what a good job is in these countries. Youth unemployment rates are twice as high as those for adults (ILOSTAT 2013). Besides, "most young people making initial transitions to employment, whatever their qualification level, spend and expect to spend considerable lengths of time in insecure and marginal employment" (Chisholm, Kovacheva 2002, 20). We can expect that this situation would influence students' attitudes toward some aspects of job quality, i.e. pay and job security. Besides, researches have shown that people in Eastern European countries prefer work rewards and job promotions (Vecerník 2003, 453) to other job qualities.

On the other hand, expectations that intrinsic job characteristics would be highly ranked are based on the age and education of our respondents: they are young, with idealistic views, belonging to a privileged and protected category of population. "Having an idealized view of their planned occupation, they anticipate that work can provide opportunities to pursue and express many of their valued goals" (Ross et al. 1999, 62). Higher levels of education also correlate with a higher evaluation of intrinsic job quality aspects. Our aim is to explore how those contradictory influences are trade-offs by students.

A previous study carried out in 2011 shows that for young people in Serbia the most important job features are pay, job security, regular monthly income and career prospects (Mojić 2012, 119). Three youth studies which were conducted in Bulgaria (2012), Macedonia (2013) and Serbia (2015), implemented the same methodology. ${ }^{1}$ Four job characteristics have been offered to young people who have been asked how important these characteristics are for them to accept a certain job. Young people in Macedonia and Serbia rank them in the same order: salary, job security, job satisfaction and, working with the people they like (Topuzovska Latkovic et al. 2013, 90; Tomanović, Stanković 2015, 41). In the Bulgarian survey, more than $3 / 4$ of young people prefer well-paid, less interesting jobs to interesting and lower paid jobs. On the other hand, they prefer a difficult job demanding responsibility to an easier job with little responsibility (Mitev and Kovacheva 2014, 125, 127).

\section{METHOD}

This paper focuses on the students' perception of job quality, in a comparative perspective. The starting assumption is that their job estimations are shaped by socioeconomic conditions: if we take into account a high unemployment rate and low wages, we can expect they would prefer extrinsic job characteristics. Besides, we can presume that there will be differences among the students' attitudes regarding their social position and family experience of unemployment. In the end, we presume that, due to previous socialization and social expectations, there would be differences between male and female students. The main research questions are: What are the most favorable qualities of jobs for students? Do they value intrinsic or extrinsic job characteristics more? Do some socioeconomic characteristics influence the perception of job quality (gender, class

\footnotetext{
${ }^{1}$ These studies are a part of the Friedrich Ebert Stiftung Youth Studies in the countries of Southeast Europe based on the Shell Youth Study.
} 
affiliation, family situation regarding employment)? Are there differences between students from Serbia, Bulgaria and Macedonia regarding job quality expectations?

The listed research questions addressed in this paper were based on data collected in an empirical research study which was carried out at three universities in Bulgaria, Serbia and Macedonia in the early 2013. The sample consists of students from three regional university centers: 586 students in Veliko Tarnovo (Bulgaria), 818 in Niš (Serbia) and 804 students in Bitola (Macedonia). ${ }^{2}$ The research was done by a survey questionnaire.

The questions are addressed by comparing frequencies of selection of particular job characteristics as important for students differing in terms of country of origin, sex, employment status and education level of parents and class affiliation. By means of factor analysis, job characteristics are subsequently reduced to a fewer number of underlining dimensions indicating extrinsic and intrinsic job quality preferences. Students are then compared according to the average factor scores for particular groups of students, based on these dimensions.

\section{DATA ANALYSIS}

Out of the 11 offered job characteristics the students selected three, which they considered the most important. The job characteristics are listed in Table 1, together with the percent of students who selected them, overall, and in each observed country. Based on previous research, we have preliminarily classified job characteristics as extrinsic ${ }^{3}$ and intrinsic. $^{4}$

Table 1 Frequency of job characteristics selected as important for students, \%

\begin{tabular}{lcccc}
\hline & \multicolumn{3}{c}{ Country } & \\
\cline { 2 - 4 } Job characteristics $^{*}$ & Serbia & Macedonia & Bulgaria & Total \\
\hline Good pay $^{*}$ & 75,7 & 79,3 & 86,5 & 79,8 \\
Job security $^{*}$ & 63,9 & 55,1 & 48,0 & 56,5 \\
Opportunity for advancement $^{*}$ & 36,9 & 30,1 & 38,1 & 34,7 \\
Family friendly (work/family life balance) $^{*}$ & 25,8 & 30,1 & 19,0 & 25,6 \\
Work interesting in itself* $^{*}$ & 31,6 & 15,5 & 27,8 & 24,7 \\
Learning and professional development opportunity $^{*}$ & 25,2 & 22,7 & 25,4 & 24,3 \\
Convenient working hours $^{*}$ Job in accordance with one's abilities $_{\text {Low pressure job }}^{*}$ & 24,4 & 25,4 & 16,0 & 22,6 \\
Autonomy and opportunity to show initiative $^{*}$ & 20,5 & 17,2 & 17,4 & 18,5 \\
Decision making opportunity $^{*}$ & 12,0 & 18,4 & 14,8 & 15,1 \\
\hline
\end{tabular}

"Marks statistically significant differences at the $\mathrm{p}<0,05$ level. Differences among countries tested by ChiSquare calculated for each job characteristic separately (selected /not selected), with df 2 .

\footnotetext{
${ }^{2}$ The research was carried out by the Centre for Sociological Research, Faculty of Philosophy, University of Niš, in cooperation with the Universities of Veliko Tarnovo and Bitola.

${ }^{3}$ Good pay, job security, family friendly (allowing for job/family life balance), convenient working hours, and low pressure job.

${ }^{4}$ Opportunity for advancement, work interesting in itself, learning and professional development opportunity, job in accordance with one's abilities, autonomy and opportunity to show initiative, and decision making opportunity.
} 
Good pay is overwhelmingly the most frequently selected job characteristic $(79,8 \%)$, followed by job security $(56,5 \%)$. The two characteristics were preliminary classified as extrinsic job characteristics. The most frequently selected intrinsic characteristic is opportunity for advancement (34,7). The least frequently selected characteristics are autonomy and decision making opportunity (10,7\% and $10 \%$ respectively). These were preliminary classified as intrinsic job characteristics. The order of preferences for particular job characteristics is broadly similar for the three countries. However, students coming from the three countries differ in respect to their preferred job characteristics. The most remarkable difference is between Bulgarian and Macedonian students. Bulgarian students prefer jobs involving work interesting in itself and opportunity for professional development (intrinsic job characteristics) to family friendly jobs and jobs with convenient working hours (extrinsic job characteristics). It is quite the opposite for Macedonian students. Indeed, work interesting in itself is among the fewest selected job characteristics among these students. Table 2 presents the distribution of choices made by male and female students in the overall sample and in each country.

Table 2 Selected job characteristics by sex and country, $\%$

\begin{tabular}{|c|c|c|c|c|c|c|c|c|}
\hline \multirow{3}{*}{ Job characteristics } & \multicolumn{6}{|c|}{ Country } & \multirow{2}{*}{\multicolumn{2}{|c|}{ Total }} \\
\hline & \multicolumn{2}{|c|}{ Serbia } & \multicolumn{2}{|c|}{ Macedonia } & \multicolumn{2}{|c|}{ Bulgaria } & & \\
\hline & $\mathrm{M}$ & $\mathrm{F}$ & $\mathrm{M}$ & $\mathrm{F}$ & $\mathrm{M}$ & $\mathrm{F}$ & $\mathrm{M}$ & $\mathrm{F}$ \\
\hline Good pay & 75,9 & 75,5 & 85,0 & $75,4^{*}$ & 85,9 & 86,8 & 81,7 & 78.5 \\
\hline Job se & 61,6 & 65,4 & 54,8 & 55,9 & 49,2 & 48,0 & 56,1 & 57,3 \\
\hline Opportunity for advancement ${ }^{*}$ & 35,7 & 37,8 & 24,6 & $34,1^{*}$ & 37,7 & 38,9 & 31,8 & 36,8 \\
\hline Family friendly ${ }^{*}$ & 23,5 & 27,4 & 28,0 & 32,2 & 14,6 & $21,6^{*}$ & 23,2 & 27,5 \\
\hline Wo & 33,2 & 30,6 & 14,3 & 16,9 & 30,2 & 26,9 & 25,1 & 24,7 \\
\hline Learning, professional development ${ }^{*}$ & 21,0 & $28,1^{*}$ & 19,0 & $25,3^{*}$ & 21,1 & 28,4 & 20,3 & 27,2 \\
\hline Convenient working hours & 23,8 & 24,7 & 26,0 & 24,5 & 20,6 & $13,5^{*}$ & 23,9 & 21,5 \\
\hline one's abilities & 20,1 & 20,9 & 15,7 & 18,4 & 18,6 & 16,7 & 18,0 & 18,9 \\
\hline Lov & 14,6 & 10,1 & 16,4 & 20,4 & 13,1 & 15,2 & 15,0 & 15,2 \\
\hline Autonomy, opportun & 10,1 & 7,4 & 10,8 & 13,1 & 13,1 & 10,8 & 11,0 & 10,3 \\
\hline Decision making opportunity & 9,1 & 8,0 & 10,5 & $16,2^{*}$ & 9,5 & $4,4^{*}$ & 9,8 & 9,9 \\
\hline
\end{tabular}

"Marks statistically significant differences at the $\mathrm{p}<0,05$ level. " Differences between male and female students in general and in each country tested by Chi-Square calculated for each job characteristic separately (selected /not selected), with df 1.

In the entire sample, for the three countries analyzed together, male and female students differ in respect to how frequently they select family friendliness, and opportunity for advancement and in-job learning and professional development, as preferred job characteristics (Table 2). Female students select these characteristics more frequently than male. These differences are particularly pronounced among Macedonian students. Among Bulgarian students, female students more frequently than male select family friendly jobs, whereas male students more frequently than female select jobs with convenient work hours and decision making opportunity. The only statistically significant difference between male and female students in Serbia is related to in-job learning and professional development which is more important for female students than for male.

We expected that the employment status of the parents would impact the students' preferences for job characteristics. In particular, we expected that students with an 
unfavorable experience of having at least one of the parents unemployed would appreciate job security more than students without such an experience. Contrary to that expectation, no statistically significant difference between groups of students differing in that respect has been recorded in regard to either of the job characteristics (job security included). A tentative explanation of this seemingly counterintuitive finding may be that students are, in a way, a self selected group of young people, with aspirations which are higher than in the average population, so that their ambitions in respect to job quality surpass job security, regardless of their parents' employment status. However, we did find an effect of the parents' employment status, when all other students were compared to those living in households where both parents were unemployed. We found that the latter preferred job security more than the former (Table 3 ).

Table 3 Selected job characteristics by employment status of the parents, \%

\begin{tabular}{lcc}
\hline & \multicolumn{2}{c}{ Employment status } \\
\cline { 2 - 3 } Job characteristics & $\mathrm{N}=2041$ & $\begin{array}{c}\text { Both parents } \\
\text { unemployed } \\
\end{array}$ \\
Good pay & 79,8 & 81 \\
\hline Job security & 56,5 & 65,4 \\
Opportunity for advancement & 34,7 & 32,1 \\
Family friendly (work/family life balance) & 25,6 & 30,9 \\
Work interesting in itself & 24,7 & 21,0 \\
Learning, professional development & 24,3 & 18,5 \\
Convenient working hours & 22,6 & 24,1 \\
Job in accordance with one's abilities & 18,5 & 16,0 \\
Low pressure job & 15,1 & 12,3 \\
Autonomy, opportunity for initiative & 10,7 & 11,1 \\
Decision making opportunity & 10,0 & 8,6 \\
\hline
\end{tabular}

* Marks statistically significant differences at the $\mathrm{p}<0,05$ level. Differences between students with both parents unemployed all other students tested by Chi-Square calculated for each job characteristic separately (selected /not selected), with df 1 .

In respect to the impact of parents' education on students' job quality preferences, we found that the mothers' education level distinguishes students' preferences more than fathers'. This is in line with previous research showing that mothers are more influential in shaping children's' values in their formative period, in general, than are fathers (Johnson, Mortimer, Heckhausen 2018; Kohn, Slomczynski, Schoenbach 1986; Lekes et al 2011). Selection of job characteristics by the mothers' education level is presented in Table 4.

The data shown in Table 4 suggest that students differ in five job characteristics depending on their mothers' education level. In respect to two extrinsic job quality characteristics, job security and family friendliness, the less educated their mothers are, the more students select these characteristics as important. In respect to two intrinsic characteristics, opportunity for advancement in a job and job involving work which is interesting in itself, the more educated their mothers are, the more students select these characteristics as important. In respect to the decision making opportunity we find that the 
least likely to select this job characteristic are students with mothers who have a secondary education.

Table 4 Selected job characteristics by the mother's education level, $\%$.

\begin{tabular}{|c|c|c|c|c|}
\hline \multirow[b]{2}{*}{ Job characteristics } & \multicolumn{3}{|c|}{ Mother's education level } & \multirow[b]{2}{*}{ Total } \\
\hline & Primary & Secondary & Tertiary & \\
\hline Good pay & 78,0 & 80,5 & 82,4 & 80,2 \\
\hline Job security ${ }^{*}$ & 61,5 & 57,4 & 52,5 & 57,5 \\
\hline Opportunity for advancement ${ }^{*}$ & 35,2 & 33,3 & 40,5 & 35,3 \\
\hline Family friendly (work/family life balance) ${ }^{*}$ & 28,9 & 26,6 & 21,7 & 26,2 \\
\hline Work interesting in itself* & 20,1 & 25,8 & 29,4 & 25,0 \\
\hline Learning and professional development opportunity & 24,8 & 23,8 & 25,8 & 24,5 \\
\hline Convenient working hours & 24,8 & 21,2 & 22,3 & 22,4 \\
\hline Job in accordance with one's abilities & 16,5 & 18,4 & 20,0 & 18,2 \\
\hline Low pressure job & 15,6 & 14,7 & 16,1 & 15,2 \\
\hline Autonomy and opportunity to show initiative & 11,3 & 9,9 & 11,3 & 10,6 \\
\hline Decision making opportunity ${ }^{*}$ & 12,5 & 8,4 & 10,1 & 9,9 \\
\hline
\end{tabular}

"Marks statistically significant differences at the $\mathrm{p}<0,05$ level. Differences among mothers' education levels

tested by Chi-Square calculated for each job characteristic separately (selected /not selected), with df 2 .

Finally, we have compared students' job quality preferences, depending on the social class of their parents. The social class scheme we have used in the analysis is based on the ISCO-8 classification of occupation (which differentiates occupations according to managerial responsibility, organizational autonomy and the level of education). The classification has been modified by the employment status of the respondents (distinguishing between owners with various numbers of employees and employees). The number of class positions has subsequently been reduced to 5, with a 6th category encompassing households with inactive heads (such as pensioners, the unemployed and students). A student's household was assigned the class position of the employed parent with a higher class position. The class scheme used has the following categories: 1 - Top managers and owners with employees, 2 - Professionals and the self-employed without employees with a university level education, 3 - Clerks, technicians and self-employed without employees, with a high school level of education, 4 Qualified workers, supervisors and foremen, 5 - Unqualified workers (including agricultural workers), and 6 - Households with inactive heads.

The results of this analysis are presented in Table 5. We have found that job quality preferences of the students belonging to different social classes differ only in respect to two intrinsic job characteristics - work interesting in itself and autonomy and opportunity for showing initiative. On the first characteristic, social classes are linearly distributed so that the higher the social class of students, the more they select interesting work as an important job quality. On the second characteristic, the two middle classes are less likely to select it than are both lower and upper classes. 
Table 5 Selected job characteristics by social class, $\%$.

\begin{tabular}{|c|c|c|c|c|c|c|c|}
\hline \multirow[b]{2}{*}{ Job characteristics } & \multicolumn{6}{|c|}{ Class } & \multirow[b]{2}{*}{ Total } \\
\hline & 1 & 2 & 3 & 4 & 5 & 6 & \\
\hline Good pay & 80,2 & 80,1 & 80,6 & 79,8 & 78,7 & 79,1 & 79,8 \\
\hline Job security & 54,4 & 52,1 & 58,7 & 58,4 & 58,1 & 59,8 & 57,3 \\
\hline Opportunity for advancement & 35,3 & 38,8 & 36,2 & 32,6 & 28,5 & 33,3 & 34,3 \\
\hline ily life balance) & 27,0 & 24,5 & 25,3 & 29,2 & 25,7 & 26,5 & 26,4 \\
\hline Work interesting in itself ${ }^{*}$ & 31,3 & 27,3 & 25,1 & 23,4 & 19,8 & 21,5 & 24,5 \\
\hline , professional devel & 24,7 & 25,2 & 22,9 & 23,3 & 25,2 & 24,6 & 24,1 \\
\hline Convenien & 24,0 & 22,5 & 20,6 & 19,5 & 24,6 & 25,3 & 22,5 \\
\hline Job il & 18,3 & 21,7 & 16,8 & 18,7 & 20,9 & 18,0 & 18,8 \\
\hline Low pressure job & 15,5 & 14,0 & 13,3 & 14,1 & 19,0 & 17,5 & 15,4 \\
\hline Autonomy and oppor & 10,3 & 13,3 & 7,2 & 8,8 & 11,9 & 12,3 & 10,3 \\
\hline Decision making opportunity & 10,3 & 9,1 & 8,1 & 10,5 & 10,7 & 12,8 & 10,2 \\
\hline
\end{tabular}

1 - Top managers and big entrepreneurs, 2 - Professionals, 3 - Clerks and technicians, 4 - Qualified workers, supervisors and foremen, 5 - Unqualified workers, 6 - Households with inactive heads.

* Marks statistically significant differences among social classes at the $\mathrm{p}<0,05$ level. Differences among classes tested by Chi-Square calculated for each job characteristic separately (selected /not selected), with df 5 .

The second part of our analysis is devoted to looking for underlying dimensions determining the selection of preferred job characteristics, by the means of a factor analysis. Prior research (a good overview is presented in: Conen and de Beer 2017) suggested that job characteristics would be selected based on preference for intrinsic vs. extrinsic jobs quality. However, our analysis of students' preferences came up with three independent dimensions determining the selection of particular job characteristics. The first dimension (which we have called Autonomy) mostly determines the selection of decision making opportunity, autonomy and opportunity for showing initiative, jobs in accordance with one's ability and low pressure jobs. Students selecting job security, and opportunity for advancement would have negative factor scores on this dimension. The second dimension (which we have called Achievement) mostly determines the selection of opportunity for advancement as well as for learning and professional development. Students selecting job security and convenient work hours would have negative factor scores on this dimension. The third dimension (which we have called Family friendly) determines the selection of convenient work hours as opposed to family friendly jobs ${ }^{5}$. Students preferring family friendly jobs would have negative factor scores on this dimension (due to the coding of job preference variables). Since the overwhelming majority of students selected good pay as a preferred job characteristic, it did not contribute to variance reduction. Consequently, we have excluded it from the factor analysis. Factor loadings for the three extracted dimensions are shown in Table 6.

\footnotetext{
${ }^{5}$ We believe that this seemingly counterintuitive finding is an artifact of the question design, according to which students were limited to only three choices (out of eleven job characteristics). If they could have selected all the characteristics, we would plausibly expect that the students who selected family friendly jobs, would also select jobs with convenient working hours - which would result in a positive correlation between the two characteristics. In fact, the opposite is the case. Under the assumption that the two characteristics do measure similar job preferences, it may be the case that the students who opted for one of the two characteristics would not select the other, and thus save their second and the third choice for characteristics measuring different job preferences. So we find a (high) negative correlation between the two characteristics.
} 
Table 6 Underlying dimensions of job characteristics, factor loadings, and \% of variance explained

\begin{tabular}{|c|c|c|c|c|}
\hline & \multicolumn{3}{|c|}{ Dimensions } & \multirow{2}{*}{$\begin{array}{c}\text { Cumulative } \\
\% \\
\text { of variance }\end{array}$} \\
\hline & Autonomy & Achievement & $\begin{array}{l}\text { Family } \\
\text { friendly }\end{array}$ & \\
\hline Convenient working hours & 233 &,- 228 & ,605 & \\
\hline Family friendly (work/family life balance) & ,166 &,- 104 &,- 757 & \\
\hline Job security &,- 269 &,- 592 & & \\
\hline Opportunity for advancement &,- 259 & ,651 & ,211 & \\
\hline Learning, professional development opportunity & ,112 &, 563 &,- 124 & \\
\hline Low pressure job &, 533 &,- 126 &, 117 & \\
\hline Job in accordance with one's abilities & ,480 & &,- 119 & \\
\hline Autonomy and opportunity to show initiative &, 553 & ,227 & & \\
\hline Decision making opportunity & ,612 & & , 102 & \\
\hline Work interesting in itself & ,321 & ,222 & ,285 & \\
\hline$\%$ of variance explained & 16,30 & 11,92 & 11,06 & 39,28 \\
\hline
\end{tabular}

The average factor scores for country, sex, employment status of the parents, the mother's education level and social class, on three extracted dimensions, are shown in Table 6. The average factor score for the entire sample is 0,00. Average factor scores for particular groups are expressed as a standardized difference from the overall average factor score. Positive average factor scores on dimensions Autonomy and Achievement indicate above average preferences for these job qualities, at the expense of more extrinsic job qualities (preference for more extrinsic job qualities is indicated by negative factor scores on these dimensions). On the dimension Family friendliness, negative factor scores indicate above average preference for this job quality, at the expense of more intrinsic job qualities. ${ }^{6}$

The dimension which differentiates students the most is Achievement. On this dimension we have found that the students differ by country, sex, employment status of their parents, the mother's education level and social class (borderline statistically significant difference). Achievement is a preferred job quality among Bulgarian students more than among Serbian and Macedonian, among female students more than among male, among students without the experience of having unemployed parents, with university level educated mothers and among students from the two upper social classes more than among students from the lower classes. On the dimension indicating students' preference for Autonomy, Macedonian students prefer Autonomy more than Serbian and Macedonian, and students from upper and lower classes more than students from the middle classes. On this dimension we have not registered statistically significant differences among students by sex and their parents' employment status and education level. On the dimension Family friendly Macedonian students prefer family friendly jobs more than Serbian and Bulgarian, and female students more than male. Students differing by employment status, education level and social class of their parents do not have different preferences on this dimension.

\footnotetext{
${ }^{6}$ This is due to the coding of the variables, and an attempt to name the underlying dimensions so that they have an intuitively appealing interpretation.
} 
Table 7 Average factor scores on three dimensions

\begin{tabular}{|c|c|c|c|c|}
\hline & & Autonomy & Achievement & Family friendly $(-)^{*}$ \\
\hline \multirow{4}{*}{ 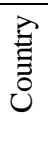 } & Macedonia & 0,10 & $-0,12$ & $-0,09$ \\
\hline & Serbia & $-0,05$ & $-0,02$ & 0,06 \\
\hline & Bulgaria & $-0,07$ & 0,19 & 0,03 \\
\hline & Statistically significant difference (F) & Sig. $=0,001$ & Sig. $=0,000$ & Sig. $=0,008$ \\
\hline \multirow{10}{*}{ 凶̃ } & Male & 0,01 & $-0,07$ & 0,06 \\
\hline & Female & $-0,01$ & 0,04 & $-0,04$ \\
\hline & Statistically significant difference $(\mathrm{F})$ & Sig. $=0,749$ & Sig. $=0,013$ & Sig. $=0,024$ \\
\hline & No unemployed parent & $-0,00$ & 0,03 & -0.01 \\
\hline & Unemployed parent & $-0,02$ & $-0,07$ & 0,01 \\
\hline & Statistically significant difference $(\mathrm{F})$ & Sig. $=0,749$ & Sig. $=0,039$ & Sig. $=0,685$ \\
\hline & Mother primary education & 0,02 & $-0,07$ & $-0,03$ \\
\hline & Mother secondary education & $-0,03$ & $-0,02$ & $-0,03$ \\
\hline & Mother tertiary education & 0,02 & 0,14 & 0,10 \\
\hline & Statistically significant difference $(\mathrm{F})$ & Sig. $=0,551$ & Sig. $=0,005$ & Sig. $=0,076$ \\
\hline \multirow{7}{*}{$\begin{array}{l}\frac{\tilde{\theta}}{0} \\
\frac{\pi}{0} \\
\frac{\pi}{0} \\
\tilde{n}\end{array}$} & Big owners, high managers, professionals & 0,03 & 0,04 & 0,04 \\
\hline & Small owners, lower managers & 0,03 & 0,12 & 0,02 \\
\hline & Routine non-manual & $-0,12$ & $-0,01$ & 0,003 \\
\hline & Technicians, foremen and qualified workers & $-0,02$ & $-0,05$ & $-0,11$ \\
\hline & Non qualified workers & 0,11 & $-0,11$ & $-0,03$ \\
\hline & Inactive parents & 0,08 & $-0,08$ & 0,01 \\
\hline & Statistically significant difference $(\mathrm{F})$ & Sig. $=0,035$ & Sig. $=0,059$ & Sig. $=0,487$ \\
\hline
\end{tabular}

"Negative scores on this dimension indicate above average preference for family friendly jobs.

For the sake of clarity, we have located students grouped by country, the education level of the mothers and social classes, in the space defined by pairs of dimensions for which we found statistically significant differences. Average factor scores on both Achievement and Autonomy for students from different countries and social class are presented on the left side of Graph 1. Groups of students with high scores on both dimensions we qualify as "leaders", groups of students with low scores on both dimensions, as "routine executors", groups of students high on Achievement, low on Autonomy - "ambitious executors", and low on Achievement, high on Autonomy - "easygoing". According to this stylized qualification, Macedonian students are more easygoing than other students; Bulgarian students are more ambitious executors than other students, while Serbian students are less easygoing than Macedonian and more routine executors than Bulgarian students.

In terms of social class, students from the two upper classes exhibit leaders who like job quality preferences, routine non manual are low on Autonomy and average on Achievement, upper working class is low on Achievement and on average on Autonomy. Students from lower working classes and inactive households are located in the easygoing quadrant - low on Achievement and high on Autonomy. 


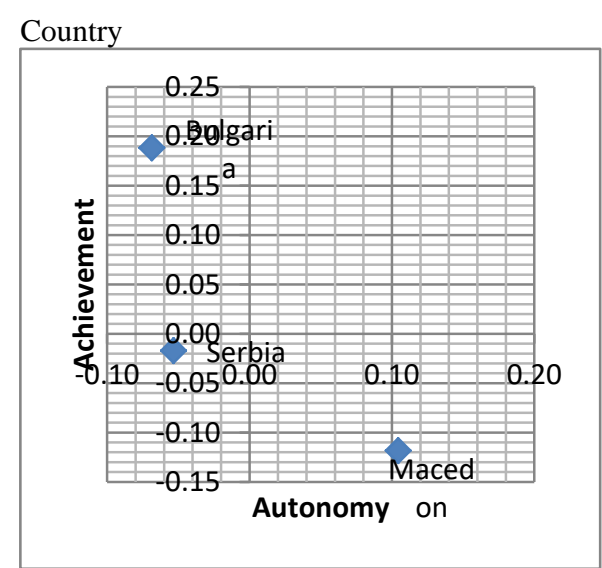

Class

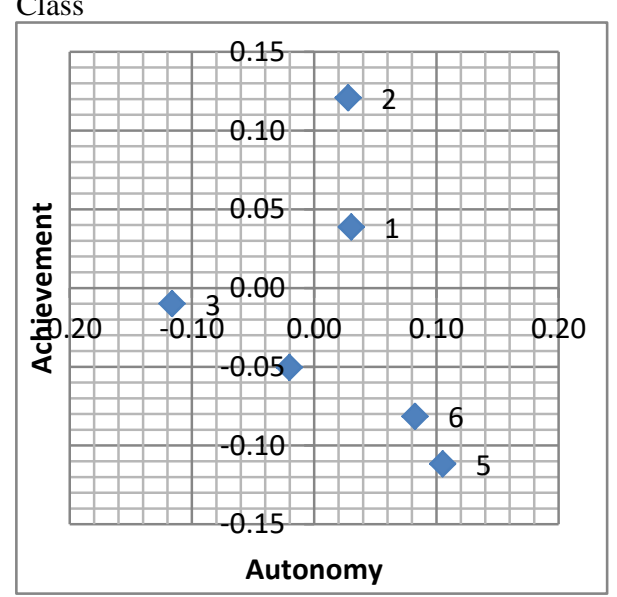

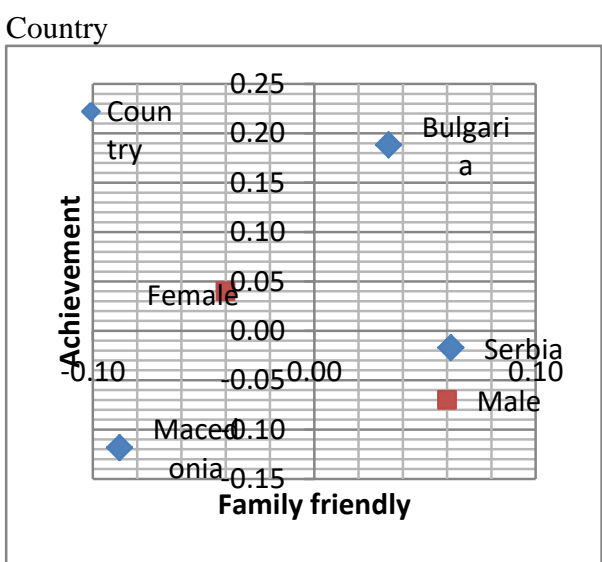

Note: Negative scores on Family friendly indicate above average preference for family friendly jobs.

Mother's education level

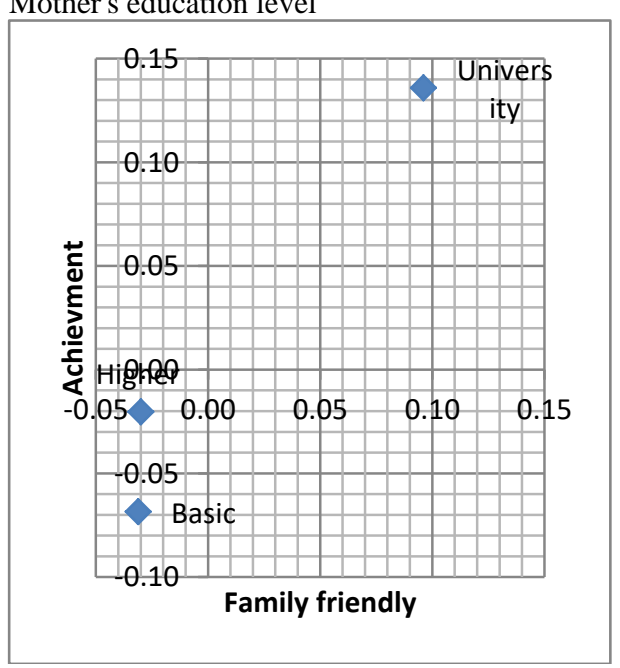

Graph 1 Average factor scores on Achievement and Autonomy (on the left side)

Average factor scores on Achievement and Family friendly (on the right side) 1 - Top managers and big entrepreneurs, 2 - Professionals, 3 - Clerks and technicians, 4 - Qualified workers, supervisors and foremen, 5 - Unqualified workers, 6 - Households with inactive heads.

In the space defined by the other pair of dimensions - Achievement and Family friendly, the two extreme quadrants could be identified as "family over career" and "career over family". While Macedonian students clearly prefer family friendly jobs over a career, Bulgarian students clearly prefer career jobs over family friendly. Serbian students less than Macedonian ones care for family friendly jobs, and less than Bulgarian ones for career jobs. In the same space students of different sex are located in the other two extreme quadrants. Male students prefer security to a career and convenient work hours to family friendly jobs. Female students are located in the "I want it all" quadrant 
(high on career and high preference for family friendly jobs, indicated by negative values on dimension family friendly). Students whose mothers have a university education are located in the "career over family" quadrant, whereas students with mothers with a high school and elementary education are located in "family over career" quadrant.

\section{SUMMARY OF THE RESULTS AND DISCUSSION}

In response to our research questions we can conclude the following.

The overwhelmingly preferred job quality among the students is good pay. Job security is the second most preferable job characteristic. This suggests the students' instrumental approach to work and preference of security over intrinsic job qualities, which could come from adverse labor market conditions in the observed countries, in the observed period. Among the intrinsic job qualities, the most preferred is opportunity for advancement - indicating students' ambition, less preferred is inner satisfaction and professional development, and the least preferred job quality is responsibility involved in jobs with a high level of autonomy, requiring initiative and decision making.

Bulgarian and Macedonian students seem to have opposite preferences for job qualities. Bulgarian students prefer jobs involving work interesting in itself and opportunity for professional development (intrinsic job characteristics) to family friendly jobs and jobs with convenient working hours (extrinsic job characteristics). It is quite the opposite for the Macedonian students. Indeed, work interesting in itself is among the fewest selected job characteristics by these students. However, Macedonian students prefer autonomy and, in particular, decision making quality in a job, more than Bulgarian students. This, in its turn, comes from Macedonian female students being keener on decision making than both Bulgarian male and female students (and both Serbian male and female students).

We have found that there is a family - career division among students regarding job quality. While Macedonian students clearly prefer family friendly jobs over a career, Bulgarian students clearly prefer career jobs over family friendly. Serbian students less than Macedonian ones care for family friendly jobs, and less than Bulgarian for career jobs. When we addressed this division through the lenses of sex, female students fare high on both career and family friendliness as job qualities, whereas male students have lower scores on both dimensions. The mother's education level proved to be relevant in this regard as well. The less educated their mothers are, the more students select job security and family friendliness over career opportunity. And the other way round, the more educated their mothers are (such as in the case of university level education), the more students select career opportunity over both family friendliness and job security.

Regarding the employment status of parents we have found that having at least one parent unemployed does not make any difference for students' preference for any particular job characteristic. However, on the more basic dimension which determines preference for job security as opposed to opportunity for advancement and professional development, students with at least one unemployed parent chose security over achievement more than the rest of the students' population. Preference for job security is even higher if both parents are unemployed.

Finally, we have found that, when job characteristics are analyzed separately from each other, social class differentiates students only in respect to their preference for two intrinsic job characteristics - work interesting in itself and autonomy and opportunity for showing 
initiative. On the first characteristic, our results indicate that the higher the social class of students, the more they select interesting work as an important job quality. On the second characteristic, the two middle classes are less likely to select autonomy and opportunity to show initiative than are both lower and upper classes. Autonomy, as is measured in this study and analyzed in this paper, seems to imply two different things. On the one hand, we may assume that for students from upper classes as well as the ones being influenced by university level educated mothers, autonomy involves leadership, initiative, responsibility, decision making. On the other hand, for the students from lowest classes and with inactive parents as well as the ones influenced by mothers with an elementary education, autonomy may indicate a job without supervision, or preference for a lack of discipline and structure in the work place. Autonomy seems to be the least important for students from routine non-manual classes, influenced by mothers with a high school education who prefer jobs which do not involve initiative and decision making, and who do not mind being supervised and organized by others in the command chain.

Acknowledgment: The paper is a part of the research done within the project Tradition, Modernization and National Identity in Serbia and the Balkans in the European Integration Process(179074), financed by the Ministry of Science and Technological Development of the Republic of Serbia and implemented by the Centre for Sociological Research at the Faculty of Philosophy, University of Niš.

\section{REFERENCES}

Carré, Françoise, Patricia Findlay, Chirs Tilly, and Chris Warhurst. "Job Quality: Scenarios, Analysis and Interventions". In Are Bad Jobs Inevitable, edited by C. Warhurst, F. Carré, P. Findlay \& C. Tilly, 1-22. London: Palgrave, 2012.

Conen, Wieteke, and Paul de Beer. "The Value of Work in a Changing Labour Market: A Review and Research Agenda." 2017. Accessed November 1, 2018. https://goldschmedingfoundation.org/wp-content/uploads/ Conen_Value_of_Work_Literature_review.pdf

Chisholm, Lynne, and Siyka Kovacheva. Exporing the European Youth Mosaic. The Social Situation of Young People in Europe. Strasbourg: Councel of Europe, 2002.

Elizur, Dov. "Facets of Work Values: A Structural Analysis of Work Outcomes". Journal of Applied Psychology 69 (184): 379-389.

Eurofound. Trends in Job Quality in Europe. Luxembourg: Publication Office of the European Union, 2012.

Galván, José Luis Álvarez. "Good or Bad Jobs? Contrasting Workers' Expectations and Jobs in Mexican Call Centres". In Are Bad Jobs Inevitable, edited by C. Warhurst, F. Carré, P. Findlay \& C. Tilly, 160-175. London: Palgrave, 2012.

Hauff, Sven, and Stefan Kirchner. "Changes in Workplace Situation and Work Values. Relations and Dynamics within Different Productive Regimes". Menagement Revue 25 (2014): 27-49. doi: 10.1688/mrev-2014-01-Hauff.

ILOSTAT Database. 2013. http://www.ilo.org/ilostat/faces/home/statisticaldata/data_by_country.

Johnson, Monica Kirkpatrick, Jeylan Mortimer, and Jutta Heckhausen. "Work Value Transmission from Parents to Children: Seeds That Sprout in Adolescence and Bear Fruit in Adulthood". Paper presented at XIX ISA World Congress of Sociology, Toronto, Canada, July 15-21, 2018.

Kalleberg, Arne L. "Work Values and Job Rewards: A Theory of Job Satisfaction". American Sociological Review 42 (1977): 124-143.

Kallebert, Arne L., and Peter V. Marsden. "Changing Work Values in the United States, 1973-2006". Social Science Research 42 (2013): 255-270. doi: 10.1016/j.ssresearch.2012.09.012.

Kohn, Melvin L., Kazimierz M. Slomczynski, and Carrie Schoenbach, 1986, "Social Stratification and the Transmission of Values in the Family: A Cross-national Assessment". Sociological Forum 1 (1986): 73-102. doi: 10.1007/BF01115074.

Lekes Natasha, Mireille Joussemet, Richard Koestner, Geneviève Taylor, Nora H. Hope, and Isabelle Gingras. "Transmitting Intrinsic Value Priorities from Mothers to Adolescents: The Moderating Role of a Supportive Family Environment." Child Development Research 2011. doi: 10.1155/2011/167146 
Mitev, Petar-Emil, and Siyka Kovacheva. Young People in European Bulgaria. Sofia: Friedrich Ebert Foundation, 2014.

Mojić, Dušan. „Obrazovani i nezaposleni. Oblikovanje radnih biografija mladih“. U Mladi - naša sadašnjost. Istraživanje socijalnih biografija mladih u Srbiji, uredila Smiljka Tomanović et al. 111-126, 301-303. Beograd: Čigoja štampa, Institut za sociološka istraživanja Filozofskog fakulteta u Beogradu, 2012.

Ross, Maria, Shalom H. Schwartz, and Shoshana Surkiss. "Basic Individual Values, Work Values, and the Meaning of Work." Applied Psychology: An International Review 48 (1999): 49-71.

Tomanović, Smiljka i Dragan Stanojević. Mladi u Srbiji 2015. Beograd: Friedrich Ebert Stiftung, SeConS, 2015.

Topuzovska Latkovic, Marija, Mirjana Borota Popovska, Eleonora Serafimovska, and Aneta Cekic. Youth Study Macedonia 2013. Skopje: Friedrich Ebert Stiftung, 2013.

UNDP. Human Development Index Report 2013

Vecerník, Jirí. "Scating on Thin Ice: A Comparison of Work Values and Job Satisfaction in CEE and EU Countries". International Journal of Comparative Sociology 44 (2003): 444-471.

Watson, Tony J. Sociology, Work and Industry, fifth edition. London, New York: Routledge, 2008.

\section{PREFERENCIJE STUDENATA U POGLEDU KVALITETA POSLA U KOMPARATIVNOJ PERSPEKTIVI}

Predmet rada je percepcija kvaliteta posla studenata iz Srbije, Makedonije i Bugarske. Polazna pretpostavka jeste da su njihove preferencije u vezi posla oblikovane društveno-ekonomskim uslovima koji postoje u ovim društvima. Sa druge strane, pretpostavljamo da je značaj koji oni pridaju određenim karakteristikama posla zavisi od zemlje u kojoj žive, pola, kao $i$ od radnog statusa i obrazovnog nivoa roditelja i klasne pripadnosti.

Ključne reči: kvalitet posla, studenti, Srbija, Makedonija, Bugarska. 